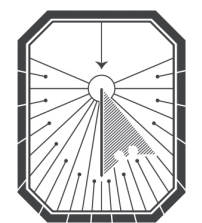

KYIV-MOHYLA

HUMANITIES JOURNAL

KYIV-MOHYLA SCHOLARLY PEER-REVIEWED JOURNALS

\title{
Re: City of Lions
}

\section{Author(s): Ostap Kin}

Source: Kyiv-Mohyla Humanities Journal 5 (2018): 201-204

Published by: National University of Kyiv-Mohyla Academy

http://kmhj.ukma.edu.ua/ 


\section{Re: City of Lions}

\section{Ostap Kin}

Shevchenko Scientific Society, New York

\section{(2)}

In the course of the past two decades, the city of Lviv has enjoyed close attention as well as a "close reading" in literary and scholarly texts on the city. This attention fits easily into two categories: (a) scholars producing academic studies on the city and (b) classical literary works on the city, composed in various languages, finally becoming available to a broader readership through translation into English. The book under discussion falls into the second category. ${ }^{1}$ It must be pointed out right away that this is an unusual book - a truly successful combination of two essays - that should be rewarded with proper attention.

Under one cover, the reader has the opportunity to enjoy two pieces that are linked together by the image of the city of Lviv. The first is an elegiac essay, Mój Lwów (My Lviv), authored by Polish writer Józef Wittlin. (This first English-language translation is by Antonina Lloyd-Jones.) The second essay is from post-201os Lviv by internationally-recognized British author Philippe Sands; it uses Wittlin's work as a springboard for Sands' own explorations of the city, or of what is left of the city from that period, mixed with a personal narrative.

My Lwów was originally published in Polish in 1946 as part of the Biblioteka Polska (Polish Library) in New York City. It is suggested that Wittlin may have been commissioned by Kazimierz Wierzyński to write such an essay. The author likely agreed in order to, in some way, complete (and verbalize) an important phase of his past life: life in/after/without Lviv. The 42 page book, completed — as mentioned at the end of the essay - on the 1st of May 1946 in Riverdale, a district of the Bronx borough of New York City, where the Polish writer found his home after immigrating to the United States in 1941, following his flight from Poland to France and Portugal.

The book is prefaced by Eva Hoffman, who herself left Poland to move first to Canada and later to the United States. Hoffman provides a very firm springboard for any reader eager to understand the city's history. By quoting Wittlin's definition that a true Lvovian is, among other things, someone with "a deep suspicion of solemnity, pretension and all pomp," this writer, too, addresses the vital questions of the policy of victimization, a lack of understanding of the past, and of distorted history. The loss and change of Central Europe that Hoffman touches upon in her preface is also partly based on Milan Kundera's celebrated essay “The Tragedy of Central Europe” (which first appeared in English translation in April 1984). In a similar way, Ukrainian writer Yurii

$1 \quad$ Józef Wittlin, Philippe Sands, City of Lions, trans. Antonia Lloyd-Jones (London: Pushkin Press, 2016). 
Andrukhovych has (re-)constructed Europe in his "autobiographical-philosophical essay" entitled "The Central-Eastern Revision," which may be viewed as an addition to Kundera's vision of Central Europe. This essay, too, is finally available in full in English translation.

Photographs of the city spanning time exist alongside the text-Wittlin's text is exclusively illustrated with old photographs from, more or less the writer's period, while contemporary images by Diana Matar are featured in Sands's part of the book. The black and white photographs chosen expressively intertwine with the stories of the past and of the present that are told in the essays, and this interplay represents one of the main themes in the book. We are given glimpses of the city: pharmacies, stairs in dimly-illuminated buildings from the early twentieth century, a woman with her head covered in a headscarf in front of semi-erased graffiti, a dungeon-like room in a dilapidated castle (naked walls, darkness, a single window), a site that could have served as a place for a massacre during World War II, streets and buildings at night, a crossing between raised railway tracks that served as an entrance to the ghetto erected during WWII.

From the very beginning of the essay, Wittlin is straightforward and discusses being perplexed, if not terrified, as he looks back "[f] or suddenly, from the bottom of our memory, monsters we would rather forget are bound to come floating to the surface of our consciousness," while, on the other hand, there is always "the risk of self-admiration" (p. 15). Wittlin's text is a hymn to a city dragged from the depths of his memory. Although the author explains how tricky memory can be, he nonetheless attempts to produce a balanced story of (his) city. Wittlin's essay should be prized for its dense, rich depictions: the portrayal of the city's train station, the depiction of the buildings left behind or lived in, the unusual and recognizable inhabitants. The author, for example, pays special attention to pharmacies, and provides observant descriptions of other locales and their roles in the story, summing up that the "pharmacy and the crime story are generally rather discrete concepts" (p. 35). The language here drifts and dissolves into a story of sensation. He seems to be preoccupied with very down-toearth moments of life. His is an encyclopedia entry of daily routine in the city known only to those who inhabit it. At the same time, Wittlin, as a true writer, resurrects the characters and events of his past, and presents a piece obsessed with tiny details and individual fates. George Grabowicz, in his essay on the mythologization of Lviv in literature, describes the contribution of the Polish writer thus:

Its greatest virtue - made all the more striking by coming so soon after the cataclysm, long before the political dust had settled and a consensus had crystallized as to the response, the rules of engagement in this national catastrophe-is its seemingly unprecedented self-reflection, the ability to see beneath the surface and beyond the visible. In tone and structure Mój Lwów is an elegy —indeed, doubly so, for it laments and celebrates the author's own youth and the city of his youth, both of which have 
now passed into oblivion. For Wittlin, however, the elegiac and nostalgic impulses are continually reformulated into tools of self-discovery and subtle revisionism. ${ }^{2}$

The tie between Lviv and New York at the time of Wittlin's arrival was not a new one for escapees from Eastern Europe. It was conveniently at work for decades, if not centuries. After the author settled down in the Bronx, he called the place "a Jewish paradise on earth," the way Lviv had been a paradise for him. ${ }^{3}$ Wittlin lauded the city of New York, a place that would be a home for him until the end of his days, in the essay "Novi Eboraci" (in New York). He continued to explore the location in such essays as "What Kind of America Did I Come to?" and "My First Year in America." Regardless of which city, Wittlin maintained a very vivid lens on the city's existence, and the way he digests both Lviv and New York suggests special attention to this - the curiosity of a special city inhabitant who possesses the features of a city-dweller formulated by Walter Benjamin.

Sands starts observing the Polish city where Wittlin, it seems to me, left it behind, but there is a time gap between them, an oblivion, an abyss, a frontier likely impossible to cross, caused by decades of rigorous erasure. New layers of the city may try covering past ones, but as Sands points out, the old keeps resurfacing: even old advertisements are still to be found on the city's walls. Found during reconstruction work, these pieces of the past in Yiddish or Polish are left like museum objects.

Sands produces a different text in response to this layered city. Entitled My Lviv, it should serve as an inner rhyme with Wittlin's My Lwów; he circles around the places Wittlin outlines in his piece, but also produces his own version of the city. For Sands, as well as for Wittlin, the city is about certain characters from the past and the evolving people inhabiting it at the present, and not only about its mesmerizing architecture, aura, and atmosphere. For Sands, this is also a deeply personal story, for part of his family has roots in Lviv. He also bases his essay (to some extent) on the work he does as an international law specialist and, thus features two renowned individuals who have contributed to the legal field, Rafael Lemkin and Hersch Lauterpacht. They both impacted and formed the city's atmosphere, suggesting that the city has managed to establish a scene that welcomes not only literati, but those from other spheres of culture and scholarship.

To conclude, I would like to illustrate how certain individuals were linked by the city. Consider, for example, a triangulated literary story that includes three men of letters: Józef Wittlin, Joseph Roth, and Izydor Berman. The first two are writers, in Polish and German, respectively. They are friends, both spending periods of their lives in Lviv (moreover, living on the same street - today called Chekhova Street), eventually leaving the city for good. One, as we already know, ended up in New York, the second almost made it there: a 1939 letter was found in the writer's room after Roth's sudden death, inviting him to visit New York and the United States. The third writer, however, is probably the least known of this trio. He is a school teacher, a contributor to leftist

2 George Grabowicz, "Mythologizing Lviv/Lwów," Harvard Ukrainian Studies XXIV (2000): 323-24.

3 Zoya Yurieff, Jozef Wittlin (New York: Twayne, 1973), 133. 
Jewish Polish-language newspapers, and a translator. Amidst his translations from Polish into German is the translation of Wittlin's magnum opus, Sol zemli (Salt of the Earth). His translations into Polish include his renditions of Joseph Roth's novels, most notably Hotel Savoy, as well as translations of Franz Kafka's works (he is regarded as one of the first translators of Kafka).

This described triangle is, first and foremost, one of the possible ways to describe the literary collaboration that took place in the city during past decades and centuries. The triangle underlines centuries-long traditions of co-existing languages, literatures, traditions, and cultures. The city of Lviv in literature has generally already been covered in scholarship. Of special interest here are studies by Dutch scholar Jan Paul Hinrichs and Polish researcher Katarzyna Kotyńska. The former based his study on writings about Lviv in different literatures (Joseph Roth, Alfred Döblin, Zbigniew Herbert, Adam Zagajewski, Günter Eich, Stanisław Lem, Alexander Granach and others), whereas the latter works with Polish literature on the city. ${ }^{4}$

City of Lions is an important book on the city. Though much attention has been paid to Lviv, the stories of the city have by no means been played out. This pair of essays gives readers an invaluable opportunity to hear the voices of ordinary people, restored and allowed to be heard, out of a vast void they were trapped in for decades.

Ostap Kin received his MLIS degree from Long Island University in 2016. Currently he is an archivist at the Shevchenko Scientific Society (New York). He has recently edited an anthology entitled New York Elegies: Ukrainian Poetry on the City (forthcoming, Academic Studies Press), and has co-translated Yuri Andrukhovych's Songs for a Dead Rooster (Lost Horse Press, 2018; with Vitaly Chernetsky). 